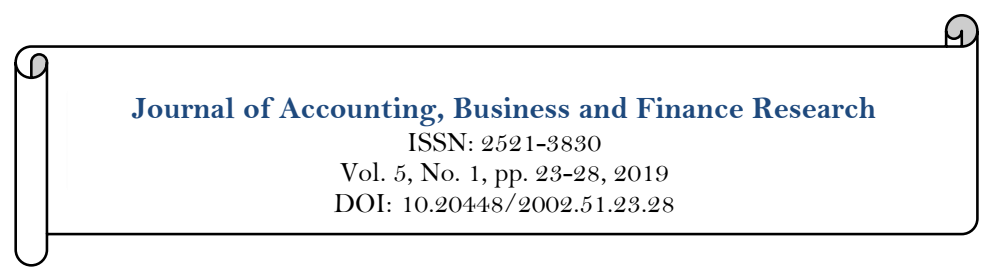

$\checkmark$ updates

\title{
The Conceptual Paper on Service Quality and Business Zakat Compliance Behaviour among SMEs in Kedah
}

\author{
Yaty Sulaiman's \\ Maria Abdul Rahman ${ }^{2}$ \\ Nik Kamariah Nik Mat ${ }^{3}$ \\ ${ }_{1,2,3}$ School of Business Management, College of Business, Universiti Utara Malaysia 06010 Sintok, Kedah, Malaysia \\ ${ }^{2}$ Email:yaty.sulaiman@yahoo.com
}

\begin{abstract}
The quality of service is an essential element in evaluating the capabilities of an institution to meet its goals. The purpose of the conceptual framework is to study the relationship between the service quality of Lembaga Zakat Negeri Kedah and the compliance of business zakat payers. The paper discussed the introduction of zakat, definition of service quality, service quality model, compliance behaviour and the relationship between service quality and compliance behavior of zakat payers. The SERVQUAL Model and Theory of Planned Behavior are discussed in this paper to measure the relationship between service quality and the compliance behavior of zakat payers. The recommendation of service quality improvement by Lembaga Zakat Negeri Kedah has been suggested in this study.
\end{abstract}

Keywords: Service quality Compliance SERVQUAL

Theory of planned behaviour Zakat institution

Licensed:

This work is licensed under

Creative Commons Attribution 4.0

License.

Publisher:

Scientific Publishing Institute

Funding: Research Granted by Lembaga Zakat Negeri Kedah (LZNK) and Institut Penyelidikan dan Inovasi Zakat (IPIZ)-UUM

Competing Interests: Zakat Compliance among SMEs in Kedah

Acknowledgement: Yaty Sulaiman is Senior Lecturer of Marketing, School of Business Management, College of Business, Universiti Utara Malaysia 06010 Sintok, Kedah, Malaysia. The author would like to thank Lembaga Zakat Negeri Kedah (LZNK) and Institut Penyelidikan dan Inovasi Zakat (IPIZ)-UUM for granting this research under the

Industry Research Grant Scheme and Research Innovation Management Centre (RIMC) Universiti Utara Malaysia.

\section{Introduction}

Zakat is one of five Islamic pillars obliged by every Muslim who has the same wealth as or exceeds the minimum set (nisab). In this case, it must provide some of it, at a certain rate for a category that has been set according to the Shariah. The person paying for zakat just not only help the poor society but also fulfill the needs of Islam in order to help to claim on himself by purifying wealth (Gambling \& Karim, 1986).

Amuda (2013) defined zakat as "an obligatory duty on financially which secure Muslims to donate or pay a specific percentage of his or her wealth to the poor in a society". According to syarak, zakat, as defined by the fuqaha, means the mandatory right to certain property with certain conditions and rules (Al-Nawawi, 2007). Al-Qaradawi (2006) defined zakat as a certain part of the property that is obliged to be issued to the eligible community.

According to Siddiqi (1968), Mannan (1986) and Zayas (2003) zakat has literally been derived from the Arabic word base which brings meaning to the cleansing and encouraging which leads to growth and improvement. According to Ataina and Ahmad (2010) by paying zakat, it may lead to increased wealth in this world as well as the development of religious merit in the hereafter. Furthermore, zakat has also been mentioned in the Qur'an along with other requirements such as "sedekah" which also carry the meaning of giving and charity (Hairunnizam, Sanep, \& Radiah, 2012). 
Zakah or zakat can literally be defined as purification. Technically, it can be defined as a sum of money that must be spent in a certain way when reaching the minimum limit of a certain amount (Nur, 2008). Zakat fitrah is obligatory zakat for all Muslims and is usually paid in Ramadan. While wealth zakat must be paid by individuals when they meet minimum zakat obligations (when the requirement of nisab and haul has been fulfilled).

A few categories such as crops and agriculture, business, natural resources, gold and silver can pay zakat on wealth. In addition, zakat must also be imposed on other categories of wealth such as savings accounts, Employees Provident Fund (EPF), bonds and anything else which is equivalent. This was agreed upon by the Contemporary Islamic Law as long as it fulfilled the necessary requirements (Farah, 2011)

The State Islamic Religious Councils (SIRCs) are the institution which responsible for managing the distribution and collection of zakat funds internally in Malaysia. However, various issues are increasingly linked to zakat management. According to Norazlina, Ahmad, Zairy, and Mahyuddin (2016) zakat issues are increasingly visible since there is no provision that zakat must be paid to the authority, no provision that prevents zakat payers from paying zakat directly to the asnaf, the institutions are said to practice favoritism and are unfair in the distribution of zakat funds and one cause that may contribute to these problems is the bad service quality of the zakat institutions which may lead to the lower level of compliance among zakat payers.

\section{Conceptual Framework}

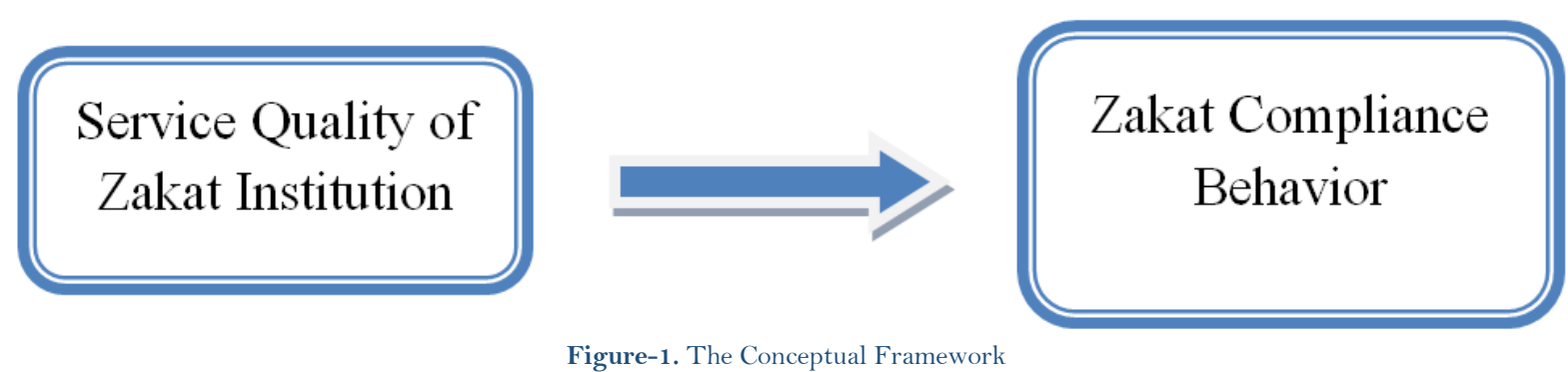

Source: Kamil (2002)

Figure-1. The Conceptual Framework

The figure above shows the conceptual framework for this paper. The conceptual framework consists of an independent variable which is service quality while compliance in paying zakat is used as dependent variable. The framework is build based on the studies on service quality and zakat payment compliance by previous researchers. Service quality, which delivered by zakat institution also has a significant relationship with the compliance of the people who paying zakat.

\section{Literature Review}

3.1. Service Quality

3.1.1. Definition of Service Quality

Service quality is an increasingly important criterion at present. Satisfaction also depends on the quality of products and services which can lead to the high-quality service. Service quality can be defined as fitness for use, conformance to requirements and freedom from variation (Kotler, Ang, Leong, \& Tan, 2013). Definition of service quality has been introduced and its measurement has become a major discourse subject among academic researchers. For example, an approach to define and measure the quality of services is by (Parasuraman, Zeithaml, \& Berry, 1985); Parasuramans, Zeithaml, and Berry (1988) which suggests that service quality can be measured by assessing the difference between user perception on service expectations.

Johnson, Anderson, and Fornell (1995) describes the quality of service is something that is intangible. The quality of services can be defined as a comparison between customer expectations of services offered and customer perceptions of service performance based on the experience gained (Gronroos, 1982; Sasser, Olsen, \& Wyckoff, 1998).

Lovelock and Witrz (2007) have stated that the company's service delivery has a customer's cognitive long-term valuation relationship. Therefore, the quality of service can be understood as a measurement method for evaluating service delivery performance in terms of customer experiences and perceptions that are formed through the service received or subscribed.

Traditionally, zakat institutions strive to provide high quality services in terms of zakat management and customer service. In an effort to do so, this institution needs to see the community as their ultimate customer and strive to maximize their satisfaction based on the services provided.

\subsection{Service Quality Model}

Service quality model is a conceptual framework developed to state the relationship that exists between factors or variables affecting service quality (Seth, Deshmukh, \& Vrat, 2005). This means a service quality 
model is a tool that illustrates service quality factor reviews and identifies service quality issues. In practice, the service quality dimensions model relates to solutions, concepts, and important issues for the quality of an organization's services. In addition, the model also shows quality improvement regarding service quality to improve organizational performance and ensure competitiveness in the future.

Seth et al. (2005) concluded that the model for service quality is a reference source for researchers to measure and evaluate service quality as it includes discussions related to dimensions of service quality measurement, data collection, data analysis, measurement scale, and service quality issues.

Among the various approaches to measure service quality was founded, but the most popular was the SERVQUAL model by Parasuraman et al. (1985); Parasuramans et al. (1988); (Zeithaml, Parasuraman, \& Berry, 1991); Ananthanarayanan, Zeithaml, and Berry (1994). The models have been used in various service industries, including banking, airline and healthcare industries. Parasuramans et al. (1988) expanded SERVQUAL to measure service quality and argued that the quality of services viewed by customers came from the comparisons of customer expectations and their perceptions of the performance delivered by the company.

According to Ghani et al (as cited in Norazlinas, Zairy, and Mahyuddin (2015) the SERVQUAL model measures the quality of service which consists of five dimensions, namely reliability, responsiveness, compliance, empathy, and tangibles as shown in Table 1 below:

Table-1. Five dimensions of service quality

\begin{tabular}{|c|c|}
\hline Dimension & Measurement items/Service attributes \\
\hline Reliability & $\begin{array}{l}\text { Performance of service in a dependable and accurate manner, staff are knowledgeable, } \\
\text { meet deadline in providing services, staff show sincere interest to assist customers, staff } \\
\text { provide service right the first time, staff give proper advice, integrated value-added } \\
\text { service that is according to Islam, staff's ability to provide courteous and knowledgeable } \\
\text { service, knowledgeable and experienced management team, friendliness of zakat } \\
\text { personnel, wide and easy access to network. }\end{array}$ \\
\hline Tangibles & $\begin{array}{l}\text { Availability and appearance of facilities and personnel, interior comfort of the } \\
\text { organization, physical facilities of the organization, external appearance such as parking } \\
\text { space, location convenience such as accessibility via public transport, counter } \\
\text { partitions/special room for customer with "issues", materials associated with the service } \\
\text { such as brochure or magazines, operation hours, number of counters during peak hours, } \\
\text { relevant forms associated with the service, facilities for disabled people. }\end{array}$ \\
\hline Empathy & $\begin{array}{l}\text { The willingness of staff to understand the needs of customers, employees understand } \\
\text { customers' needs, employees give personal attention, employees have a sense of humour, } \\
\text { employees take care of customers' specific needs, confidentiality of customers' } \\
\text { information. confidentiality of customers' moral issues, value-added services in terms of } \\
\text { financial/personal counseling, zero service charge, availability of user-friendly forms, } \\
\text { value-added services such as photocopy service and filling forms for customers. }\end{array}$ \\
\hline Responsiveness & $\begin{array}{l}\text { Willingness of staff to assist customers and provide prompt service, employees' } \\
\text { knowledgeable about zakat, employees always willing to assist customers, ability to fulfil } \\
\text { individual needs, courteous counter service staff, fast and efficient counter service, } \\
\text { number of branches available, prompt service, one-stop centre that has everything under } \\
\text { one roof, number of staff/counters available, staff never too busy to respond to customers' } \\
\text { needs. }\end{array}$ \\
\hline Compliance & $\begin{array}{l}\text { Not involved in any interest-paid/taken activities, investment only in Islamic compliant } \\
\text { financial institution, financial transactions only with Islamic-compliant financial } \\
\text { institution, in-house religious advisors dispose of non-Shariah-compliant earnings, fulfill } \\
\text { its social role as well as promote Islamic finance, not contradictory to Islamic teaching, } \\
\text { incorporates Islamic business ethical principles. }\end{array}$ \\
\hline
\end{tabular}

\subsection{Compliance Behaviour}

3.3.1. Theory of Planned Behavior and Compliance Behaviour of Zakat Payers

The study of zakat compliance is more about the topic of compliance behavior. Based on the various literature on Zakat compliance theory various theories are used according to their respective designs. Most studies on compliance behavior use psychology theory as a framework of study by using the Theory of Planned Behavior (TPB) as the basis and this is the most popular approach. TPB was developed by Ajzen (2011). Recently, avoidance and compliance model being built to examine the zakat compliance behavior in sociology, economic and theory of psychology (Ahmad \& Zulkifli, 2010).

In Malaysia, it begins with a study by Kamil (2002) where the study was conducted to identify the dimensions of attitude towards pay zakat and to formulate compliance model of salary-related obedience to understand how the affected variables influence the behavior of compliance. Among other researchers that also use TPB as their research framework, for example, Ahmads (2009) who conducted the studies to look at the 
effects of religious level and personal accountability on the intention of paying business zakat among single ownership merchants. In addition, other researchers such as Nor (2011) conducted a study on compliance with business zakat among gas station operators and Ram (2010) that focused on the compliance behavior of business zakat among businesses in Kedah.

\subsection{The Relationship between Service Quality and Compliance Behavior of Zakat Payers}

Service quality that delivered by the zakat institution will increase the compliance of zakat payers. According to Sahidi (2013) he stated that the important factor in attracting and promoting businesses paying zakat is through the quality of services provided and delivered by zakat institutions. He argued that service is quality when a company or organization meets the customer expectations in terms of before and after the service. In addition, Saad, Kamil, and Zainol (2009) demonstrates empirical evidence that with improved service quality, zakat compliance will be better. It is assumed that the quality of zakah institution services will affect the compliance of zakat payers.

Adibah and Tamkin (2014) in their studies have shown that among the key elements of service quality satisfaction were the variety of payment facilities available to the public. The study clearly exposed that the quality of services provided by the zakat institution greatly influences the level of awareness of zakat payments by zakat payers. In addition, good community perceptions of zakat institutions will increase the payment of zakat to zakat institutions and on the other hand if the perception of the society is weak then it will lower the rate of zakat collection by zakat centre. This is supported by the study of Hairunnizam, Sanep, and Radiah (2009) which shows that most respondents do not pay zakat as likely to be dissatisfied with the distribution of zakat by zakat institutions.

Studies on service quality have been conducted by many researchers. For example, Staples, Dalrymple, and Bryar (2002) stated that service quality is an important instrument for winning trust and patronage, the satisfaction of customer and customer loyalty. In the area of zakat, Hillman and Dalziel (2003) argued that service quality plays an important role in compliance to zakat payment. Besides that, Ram (2010) reveals that well-organized service quality in zakat organization influence intention to pay zakat.

In relation to zakat institutions, Kamil (2005) emphasized that quality-conscious services are one of the intrinsic motivations of Muslim individual factors to pay zakat. Research by Ram-Al, Wahab, and Samsudin (2016) conducted on Muslim businessman in Malaysia. They conducted a study on two internal factors and two external factors. Internal factors consist of knowledge and self-efficacy while internal factors are interaction and service quality. They have found that the quality of service has an influence on the compliance of zakat payments on businesses.

Several years later, Saad-Ram, Wahab, and Hussain (2018) carried out to examine the perceived quality of services towards zakat institutions. The study was conducted among 227 Muslim businessmen in one of the states in Malaysia. The findings have shown that most respondents have evaluated "Good" for three aspects of quality, namely tangibles, reliability and courtesy. Meanwhile, other aspects of quality such as credibility, efficiency, responsiveness, access, understanding and communication are rated as "Bad". Between the 9 aspects of service quality, only 3 aspects were rated "good" and 6 aspects were rated as "bad". This has shown how weak the quality of service perceived by zakat payers towards zakat institutions.

Azman, Mursyid, and Muhammad (2018) conducted a preliminary survey at the mosque institution in Selangor. They found that zakat management practices in the mosque institution in the state of Selangor more focused on the opening of Mini Counter of Lembaga Zakat Selangor (LZS) services as an initiative and progressive measures in the implementation and management of zakat. Researchers have stated that LZS plays an important role in educating the society towards the awareness of zakat by providing zakat collection services and managing the distribution of zakat to eligible and needy groups. LZS has also taken initiatives and more progressive measures to assist the ummah in implementing zakat business by opening a zakat payment service counter in some parts of the state of Selangor known as LZS Mini Counter.

Zakat institutions are responsible for providing services related to the management of zakat funds. The management of zakat funds should be well managed as this will lead to the credibility of zakat institutions as well as raising customer perceptions of the services provided.

\section{Recommendation}

The zakat institutions involved should improve the quality of their services to ensure the effectiveness and efficiency of zakat in assisting the asnaf, facilitating zakat related governance and increasing the socioeconomic status of the country. Furthermore, instant improvements should be taken by zakat institutions to further improve the quality of services delivered to asnaf and zakat payers. Enhancing staff knowledge, awareness of paying zakat, furniture infrastructure and the use of modern technology compared to what is currently being used and applied.

For the long-term strategy, zakat institutions can implement educational services such as early education programs on the realization of paying zakat and business zakat starting from schools and universities. This early education is not limited to religious subjects but can be extended to other subjects such as accounting, 
finance and business studies where the subject of calculating zakat can be used as one of the subtopics of the appropriate subjects.

\section{Conclusion}

The quality of services plays an important role in zakat institution. Quality service of zakat institution has relationship towards compliance behaviour of zakat payers. Good service and quality become part of the basic elements of the institution to succeed. Awareness of improving the quality of these services is no longer an easy thing but it is a serious responsibility to carry out. Therefore, zakat institutions need to streamline the work process by combining the latest technology to produce services that always exceed customer expectations, and this can increase the compliance of zakat payers. This service needs to be based on Islamic morals in an atmosphere of applying the elements of worship in line with zakat claims that are performed to get the pleasure of Allah SWT.

\section{References}

Adibah, A. W., \& Tamkin, B. J. (2014). Payout factors Zakat by business entities in Malaysia: A review of theory. Shariah Journal, 2(3), 267-294.

Ahmad, S., \& Zulkifli, D. (2010). Models of compliance behavior and zakat evasion: A theoretical review. . Paper presented at the In Seventh International Conference-The Tawhidi Epistemology: Zakat and Waqf Economy.

Ahmads, R. B. G. (2009). Impact of religious levels and personal accountability on the intentions of paying Zakat for business among Penang's single business contractor. Master of Arts in Literature, University of Science Malaysia.

Ajzen, I. (2011). The theory of planned behavior: Reactions and reflections. Psychology \& Health, 26(9), 11 13-1 127.

Al-Nawawi, Y. B. S. (2007). Al-Majmu 'Syarh al-Muhadhdhab (Vol. 7). Beirut: Daral-Kutub Al-Ilmiyyah.

Al-Qaradawi, Y. (2006). Ibn al-Qariah wa al-Kuttab (Vol. 1). Kaherah: v.

Amuda, Y. J. (2013). Empowerment of Nigerian muslim households through waqf, zakat, sadaqat and public funding. International Journal of Trade, Economics and Finance, 4(6), 419-424.

Ananthanarayanan, P., Zeithaml, V. A., \& Berry, L. L. (1994). Reassessment of expectations as a comparison standard in measuring service quality: Implications for further research. Journal of Marketing, 58(1), 111-124.

Ataina, H., \& Ahmad, T. (2010). Management of zakah: Centralized Vs decentralized approach. Paper presented at the 7 th International Conference-The Tawhidi Epistemology: Zakat and Waqf Economy. Bangi, Selangor.

Azman, R. A., Mursyid, J. F. M., \& Muhammad, N. W. A. (2018). Zakat management practice in Mosque institutions in Malaysia: An initial survey in Selangor. Journal of Fatwa Management and Research, 13(1), 155-162.

Farah, M. N. A. (2011). Zakat compliance intention behavior on saving among Universiti Utara Malaysia"s staff. Unpublished Master Dissertation, Universiti Utara Malaysia.

Gambling, T. E., \& Karim, R. A. A. (1986). Islam and 'social accounting'. Journal of Business Finance \&’ Accounting, 13(1), 3950 .

Ghani, E. K., Jamaliah, S., Siti, N. H. Z., \& Sharifah, N. S. Y. (2012). Composite performance measurement for Zakat organizations. British Journal of Economics, Finance and Management Sciences, 4(1), 50-59.

Gronroos, C. (1982). Strategic management and marketing in the service sector. Helsingfors: Swedish School of Economic and Business Administration.

Hairunnizam, W., Sanep, A., \& Radiah, A. K. (2009). Distribution of zakat by the institution of zakat in Malaysia: Why do Muslims are dissatisfied? Journal of Sharia, 17(1), 89-112.

Hairunnizam, W., Sanep, A., \& Radiah, A. K. (2012). Localize administration of Zakah Distribution: The role of Mosque Institutions in Malaysia. Asian Journal of Accounting and Governance, 3(1), 71-83.

Hillman, A. J., \& Dalziel, T. (2003). Boards of directors and firm performance: Integrating agency and resource dependence perspectives. Academy of Management Review, 28(3), 383-396.

Johnson, M. D., Anderson, E. W., \& Fornell, C. (1995). Rational and adaptive performance expectations in a customer satisfaction framework. Journal of Consumer Research, 21(4), 695-707.

Kamil, M. I. (2002). The Zakat compliance behavior among public civil service officers in Kedah. Doctorate Thesis, Universiti Utara Malaysia.

Kamil, M. I. (2005). The role of intrinsic motivational factors on compliance behavior of zakat on employment income, in Zakat Contemporary Issues in Malaysia (1st ed., pp. 137-170). Melaka: IKAZ, UiTM.

Kotler, P., Ang, S. H., Leong, S. M., \& Tan, C. T. (2013). Marketing management: An Asian perspective (6th ed.). Singapore: Prentice Hall.

Lovelock, C., \& Witrz, J. (2007). Service marketing: People, technology and strategy (3rd ed.). New Jersey: Pearson Prentice Hall.

Mannan, M. A. (1986). Islamic economics: Theory and practices. Cambridge:: Hodder and Stroughton.

Nor, A. A. S. (2011). Compliance to business Zakat: A review of the stations of oil station operators in Penang. Master's Degree, Universiti Utara Malaysia.

Norazlina, A. B., Ahmad, Z. B., Zairy, Z., \& Mahyuddin, A. B. (2016). The impact of service quality on Zakat Stakeholders Satisfaction: A Study on Malaysian Zakat Institutions. The Journal of Muamalat and Islamic Finance Research, 13(2), 71-91.

Norazlinas, A. W., Zairy, Z., \& Mahyuddin, A. B. (2015). Towards developing service quality index for zakat institutions. Journal of Islamic Accounting and Business Research, 8(3), 326-333.

Nur, B. A. B. (2008). A Zakat accounting standard (ZAS) for Malaysian companies. The American Journal of Islamic Social Sciences, 24(4), 74-92.

Parasuraman, A., Zeithaml, V. A., \& Berry, L. L. (1985). A conceptual model of service quality and its implications for future research. Journal of Marketing, 49(4), 41-50. 
Parasuramans, A., Zeithaml, V. A., \& Berry, L. L. (1988). Servqual: A multiple-item scale for measuring consumer perc. Journal of Retailing, 64(1), 12-40.

Ram-Al, S. J., Wahab, M. S. A., \& Samsudin, M. A. M. (2016). Factors influencing business Zakah compliance behavior among moslem businessmen in Malaysia: A research model. Procedia-Social and Behavioral Sciences, 219, 654-659.

Ram, A. S. (2010). Behavioral business Zakat compliance in Kedah Darul Aman. Thesis of PhD, Universiti Utara Malaysia.

Saad-Ram, A. J., Wahab, M. S. A., \& Hussain, M. H. M. (2018). Perceived service quality of zakat institution among Muslim businessmen in Malaysia. Paper presented at the AIP Conference Proceedings.

Saad, A. L. F., Kamil, M. I., \& Zainol, B. (2009). Zakat payment rules to zakat institutions: The attitude of the trader and his effect on the behavior of business zakat payments. Journal of Syariah, 17(3), 607-630.

Sahidi, J. (2013). Determination of business Zakat on entrepreneurs in Malaysia. Journal of Management JAWHAR, 7(2), 1738

Sasser, W. E., Olsen, R. P., \& Wyckoff, D. D. (1998). Management of service operations: Text, cases, and readings. Boston (Mass): Allyn and Bacon.

Seth, N., Deshmukh, S., \& Vrat, P. (2005). Service quality models: A review. International Journal of Quality \& Reliability Management, 22(9), 913-949.

Siddiqi, S. A. (1968). Public finance in Islam. Lahore, Pakistan: S. H. Muhammad Ashraf.

Staples, W., Dalrymple, J., \& Bryar, R. (2002). Assessing call centre quality using the SERVQUAL model. Paper presented at the 7 th International Conference on ISO.

Zayas, F. G. (2003). The law and institution of Zakat. Kuala Lumpur: The Other Press.

Zeithaml, V. A., Parasuraman, A., \& Berry, L. L. (1991). Refinement and reassessment of the SERVQUAL scale. Journal of Retailing, 67(40), 420-450. 